\title{
The Effect of Trust and Brand Image on Customer Retention with Customer Loyalty as Intervening Variables to Customers of Sharia Commercial Banks
}

\author{
Nadia Adriane Ricadonna ${ }^{*}$, Muhammad Saifullah2, Ari Kristin Prasetyoningrum ${ }^{3}$ \\ 1,2,3Faculty of Economics and Islamic Business UIN Walisongo Semarang, Indonesia \\ *Corresponding Author: nadiaadrianer@yahoo.com
}

\begin{abstract}
Sharia banking is currently facing a very competitive industry era. Customer retention is one of the phenomena confronted by Islamic banks in Indonesia. Therefore, the problem in this research is how to increase customer retention in the Islamic banking sector. This study also aims to test and analyze the effect of trust and brand image on customer retention with customer loyalty as an intervening variable. A total of 100 customer respondents who have saving accounts for more than five years at Sharia Bank filled out the questionnaire in this study. The collected data were processed using the Smart PLS program with measurements of the inner and outer model tests. The test results proved that trust, brand image, and customer loyalty positively and significantly affect customer retention in Islamic commercial banks. Meanwhile, indirect testing proved that the customer loyalty variable could mediate customer trust and retention variables. However, it is unable to mediate the brand image variables on customer retention.
\end{abstract}

Keywords: Trust; Brand Image; Customer Loyalty and Customer Retention.

\section{INTRODUCTION}

Customer retention plays an essential role in the manufacturing and service industries, especially in Islamic banking. Sharia Bank functions as a financial intermediary that collects funds from the public in the form of deposits and flows back in financing to the public. In implementing the marketing strategy, Islamic banking is looking for new customers and retaining existing customers or what is known as customer retention. The development of Islamic banking is marked by the increase in the number of customers in the last five years. Several studies have examined the importance of customer retention in the Islamic banking sector. The first factor that influences customer retention is customer loyalty. According to Hanaysha (2018), customer retention has been considered the main goal for organizations focusing on relationship marketing strategies. Customer retention is defined as the process of building customer loyalty for a particular brand.

Meanwhile, Omoregie et al. (2019) believe that the higher customer loyalty, the higher the customer retention. This study contradicts a study conducted by HofmanKohlmeyer (2016), which reveals that customer loyalty does not guarantee customer 
retention. According to Preikschas et al. (2017), customer retention is an interaction between producers and customers that can bring social and economic benefits. The indicators that affect customer retention include adaptation, relationship management, and recommendations. According to Coussement (2014), customer retention is considered the company's ability to retain its customers to continue to trust the products they produce. Nillie et al. (2013) assert that customer retention is a long-term relationship between a customer and an organization that can produce a profitable relationship. The factors that affect customer retention include reliability, rangeability quality, customer loyalty, and customer satisfaction.

The second factor affecting customer retention is trust. Chu et al. (2012) state that loyalty depends on trust. Meanwhile, according to Chang and Hung (2018), trust affects customer loyalty with satisfaction as a mediation. This study contradicts the study conducted by Akintunde (2016), which states that there is no significant relationship between trust and customer retention. According to Reiersen (2019), it is stated that trust is the transfer of an excellent action to someone with the expectation that the good will be paid even though there is no guarantee. Meanwhile, according to Yu et al. (2015), trust can be seen as a mechanism to reduce transaction barriers. Trust indicators include honesty, reliability, and lack of worry.

The third factor that affects customer retention is brand image. According to Andreassen and Lindestad (1998), brand image can provide extraneous informative cues for potential buyers but does not affect loyalty. Meanwhile, Faullant et al. (2008) agree that brand image can increase customer loyalty compared to satisfaction. This study is supported by the study conducted by Narteh and Braimah (2019), claiming that brand image has a positive and significant effect on customer retention in the Banking sector. An increase did not match the increase in the number of third-party fund customers in Islamic Banks in the last five years in the percentage of growth. Abosag and Farah (2014) stated that brand image is the most important component to support and maintain a company's position on the market map. Brand image indicators include different brands among competitors, attractive brands, recognizable colors, and designs.

Meanwhile, in the opinion of Espinosa et al. (2018), brand image is considered the most important strategy to encourage customers to continue buying products predicted by a company. The study conducted by Johansson et al. (2018) suggests that a brand image can be conceptualized as a consumer's perception of a brand that is formed in the minds of the consumers. Nguyen and Leblanc's (1998) research declare that company image can influence customer retention decisions. Company image is also influenced by service quality, customer satisfaction, and perceived service value. Brand image has a role, and a good customer retention decision becomes the consequence.

The last factor that affects customer retention is customer loyalty. On the report of Kashif et al. (2015), customer loyalty is a strong commitment to repurchase a product consistently in the future. Customer loyalty indicators include:

1. Customers recommend Sharia Banks to family, friends, and relatives.

2. Word of mouth is to say positive things about Islamic banking.

3. The customer will return to using the services at the Sharia Bank. 
Studies conducted by Milan et al. (2018) state that customer loyalty is a customer commitment to buy or use a certain product or service that results in consistent purchases. In the meantime, Yu dan Tseng (2016) agree that customer loyalty is the intention of consumers to buy back or promote a product or company. Customer loyalty indicators include repurchase intention and willingness to recommend. The development of Islamic banking is marked by the increasing number of Islamic banks in Indonesia. In 2019, there were 14 Sharia Commercial Banks, 20 Sharia Business Units, and 164 Sharia Rural Banks. The Financial Services Authority (OJK) stated that the number of Sharia Bank customers had reached 15 million, and the number of Conventional Bank customers has reached 80 million. Until 2019, the acquisition of a Sharia Bank market share only reached 5.33\% of the composition of the assets of BUS, UUS, and BPRS. Meanwhile, the market share of Conventional Banks has reached $94.67 \%$.

The number of third-party fund customers and growth percentage can be seen in table 1:

Table 1. Third Party Fund Customers and Percentage of Growth

\begin{tabular}{ccc}
\hline Year & Third Party Funds & Growth (\%) \\
\hline 2015 & 14.761 .002 & $23,62 \%$ \\
2016 & 18.521 .091 & $25,47 \%$ \\
2017 & 21.692 .463 & $17,10 \%$ \\
2018 & 24.334 .556 & $12,10 \%$ \\
2019 & 27.273 .711 & $12,07 \%$ \\
\hline
\end{tabular}

Source: Financial Services Authority (OJK), 2019.

Based on table 1, it is known that the number of customers of Islamic Bank thirdparty funds has increased from 2015-2019. However, the growth rate of third-party fund customers has decreased in the last five years. In 2015, the percentage growth of Sharia Bank customers was 23.6\%, whereas, in 2016, the percentage of customer growth was $25.47 \%$. However, in 2017 there was a significant decrease, namely $17.10 \%$. Furthermore, in 2018 the increase in the number of third-party fund customers also decreased from the previous year of $12.10 \%$. Until the end of 2019 , the percentage of customer growth was $12.7 \%$. This is because it has reduced from the previous year. In the last five years, the development of third-party fund customers has decreased continuously. Therefore, Sharia Banks are deemed necessary to increase efforts to increase the growth in the number of third-party fund customers.

As Ratih (2015) stated, Islamic Banks strive to increase third party fund customers by doing massive marketing in acquiring new customers and retaining existing customers to not move to other banks. Meanwhile, according to Zineldin (2006), not all loyal customers will survive in the long term. This research contradicts the research conducted by Hanaysha (2018), which declares that customer loyalty has a positive and significant effect on customer retention. According to Chang and Hung (2018), trust can affect customer retention with satisfaction as a mediation. This research disapproves of the research conducted by Akintunde (2016), which states that there is no significant relationship between trust in customer retention. The study conducted by Nguyen dan Leblanc (1998) claims that brand image can increase customer retention in the banking industry. This research contradicts the research conducted by Kassim dan Souiden (2007), which affirms that brand image has no significant effect on customer retention. 


\section{METHODS, DATA, AND ANALYSIS}

This study used a quantitative research approach that examined trust and brand image on customer retention with customer loyalty as an intervening variable. The population in this study were all third-party fund customers of Islamic Commercial Banks. The sampling technique in this study was purposive with criteria for Sharia Bank customers who have had savings of more than five years. One hundred third-party fund customers filled out a questionnaire in this study. The primary data in this study were a questionnaire given to third-party fund customers of Islamic Commercial Banks. The questionnaire was given via google form. The data measurement technique used a Likert scale using a number arrangement 1-5. Category 1 strongly disagrees, two disagrees, three disagrees, four agrees, and five strongly agrees.

In this study, the data analysis technique was Structural Equation Model (SEM), using a path analysis program to test the outer and inner models. Outer model test validity and reliability tests. The validity test was measured using convergent validity and discriminant validity, while the reliability of the test was measured by composite reliability and Cronbach alpha. While the inner model test was measured using the $\mathrm{R}^{2}$ test, which was a goodness fit model test, and was also measured using the statistical t-test with a significance level $(\alpha=5 \%)$. The regression equation in this study is as the following equation (1) and equation (2):

$$
\begin{aligned}
& \mathrm{Y} 1=\beta 1 \mathrm{X} 1+\beta 2 \mathrm{X} 2+\mathrm{e} 1 . \\
& \mathrm{Y} 2=\beta 1 \mathrm{X} 1+\beta 2 \mathrm{X} 2+\beta 3 \mathrm{Y} 1+\mathrm{e} 2
\end{aligned}
$$

$\beta 1$ : Trust Regression Coefficient.

$\beta 2$ : Brand Image Regression Coefficient.

$\beta 3$ : Customer Loyalty Regression Coefficient.

$\mathrm{X} 1$ : Trust.

$\mathrm{X} 2$ : Brand Image.

Y1: Customer Loyalty.

Y2: Customer Retention.

e1: Error.

e2: Error.

\section{RESULTS}

\section{Respondents Profile}

The characteristics of the respondents in this study include gender, age, education, and length of time as a customer. The characteristics of the respondents can be seen in Table 2. Based on table 2, it can be explained that out of 100 research respondents, 71 (71\%) are male, and $29(29 \%)$ are female. The characteristics of respondents seen from age indicate that respondents aged 20-30 are 94 people (94\%.) Respondents aged 31-40 are 3\%, and respondents aged $41-50$ are three people (3\%). The characteristics of respondents seen from education show that respondents with the latest diploma education are 14 people (14\%), respondents with undergraduate education are 81 people $(81 \%)$, and respondents with the latest S2 or S3 education are five people (5\%). The characteristics of respondents seen from how long they have become customers show that as many as $83(83 \%)$ of respondents have used Islamic Bank for 5-6 years. Meanwhile, 17 respondents (17\%) have used Islamic Bank for more than 6 years. 
Table 2. Respondents Profile

\begin{tabular}{lcc}
\multicolumn{1}{c}{ Respondent Profile } & Amount & Percentage \\
\hline Gender : & 71 & $71 \%$ \\
-Man & 29 & $29 \%$ \\
-Woman & & \\
Age : & 94 & $94 \%$ \\
-20-30 Age & 3 & $3 \%$ \\
-31-40 Age & Amount & Percentage \\
\hline \multicolumn{1}{c}{ Respondent Profile } & & $3 \%$ \\
\hline Age : & 3 & - \\
-41-50 Age & - & - \\
-51-60 Age & & $14 \%$ \\
Education : & - & $81 \%$ \\
-High School & 14 & $5 \%$ \\
-Diploma & 81 & - \\
-Bachelor & 5 & - \\
-S2/S3 & & $83 \%$ \\
Long Been a Customer : & - & $17 \%$ \\
-1-2 Year & - & \\
-3-4 Year & 83 & \\
-5-6 Year & 17 & \\
- >6 Year & &
\end{tabular}

Source: Processed Data

\section{DATA ANALYSIS}

\section{(Outer Model Result)}

Based on table 2, it can be explained that out of 100 research respondents, 71 (71\%) are male, and $29(29 \%)$ are female. The characteristics of respondents seen from age indicate that respondents aged 20-30 are 94 people (94\%.) Respondents aged 31-40 are 3\%, and respondents aged $41-50$ are 3 people $(3 \%)$. The characteristics of respondents seen from education show that respondents with the latest diploma education are 14 people $(14 \%)$, respondents with undergraduate education are 81 people $(81 \%)$, and respondents with the latest S2 or S3 education are five people (5\%). The characteristics of respondents seen from how long they have become customers show that as many as $83(83 \%)$ of respondents have used Islamic Bank for 5-6 years. Meanwhile, 17 respondents (17\%) have used Islamic Bank for more than six years.

The measurement of the outer model is measured by validity and reliability tests. The validity test is measured by convergent validity, while the reliability test is measured by composite reliability. The indicator is valid if the loading factor value is more than 0.5 , or the statistical $\mathrm{T}$ value is greater than $\mathrm{T}$ table $1.96(\alpha=5 \%)$. Trust indicators consist of meetings (X1.1), customers are the top priority (X1.2), communication (X1.3), customers receive favorable services (X1.4), loyal customers use services and services at Sharia Bank (X1.5). The results of the convergent validity test, which consist of 5 trust indicators, have a loading factor value of more than 0.5 , and the statistical $\mathrm{T}$ value of all indicators is greater than the T table value of 1.96. Hence, the trust indicator is declared valid. The results of the composite reliability test showed satisfactory results of 0.863 . This means that the trust construct can provide relatively the same results when re-measured on the same subject. 
Indicator brand image consists of easily recognizable Sharia Bank brand (X2.1), Sharia Bank brand easy to remember (X2.2), good Sharia Bank brand characteristics (X2.3), good Sharia Bank brand image (X2.4), symbol and the logo on Islamic Bank is easy to remember (X2.5). The convergent validity test, which consists of 5 Brand Image indicators, has a loading factor value of more than 0.5 , and the statistical $\mathrm{T}$ value of all indicators is greater than the $\mathrm{T}$ table value of 1.96 . So, the brand image indicator is declared valid. The results of the composite reliability test showed satisfactory results of 0.889 . This means that the Brand Image construct can provide relatively the same results when re-measured on the same subject.

Customer loyalty indicators consist of word of mouth (Y1.1), recommending Sharia Banks to families (Y1.2), recommending Sharia Banks to someone who asks for advice (Y1.3), customers returning to using services and services at Sharia Banks ( Y1.4), and the customer will use Islamic Bank in the future (Y1.5). The convergent validity test, which consists of 5 indicators of customer loyalty, has a loading factor value of more than 0.5 . The statistical $\mathrm{T}$ value of all indicators is greater than the $\mathrm{T}$ table value of 1.96 . As a result, the customer loyalty indicator is declared valid. The results of the composite reliability test showed satisfactory results, namely 0.850 . This means that the construct of customer loyalty can provide relatively the same results when re-measured on the same subject.

Customer retention indicators consist of meetings (Y2.1), customers are the top priority (Y2.2), communication (Y2.3), profitable service (Y2.4), loyal use of services and services (Y2.5). The convergent validity test, which consists of 5 customer retention indicators, has a loading factor value of more than 0.5 , and the statistical $\mathrm{T}$ value of all indicators is greater than the $\mathrm{T}$ table value of 1.96. Consequently, the customer retention indicator is declared valid. The results of the composite reliability test showed satisfactory results, namely 0.807 . This means that the customer retention construct can provide relatively the same results when re-measured on the same subject.

\section{(Inner Model Result)}

The inner model test consists of the t-test and $\mathrm{R}^{2}$ test. The following is the path analysis model, which can be seen in figure 1 .

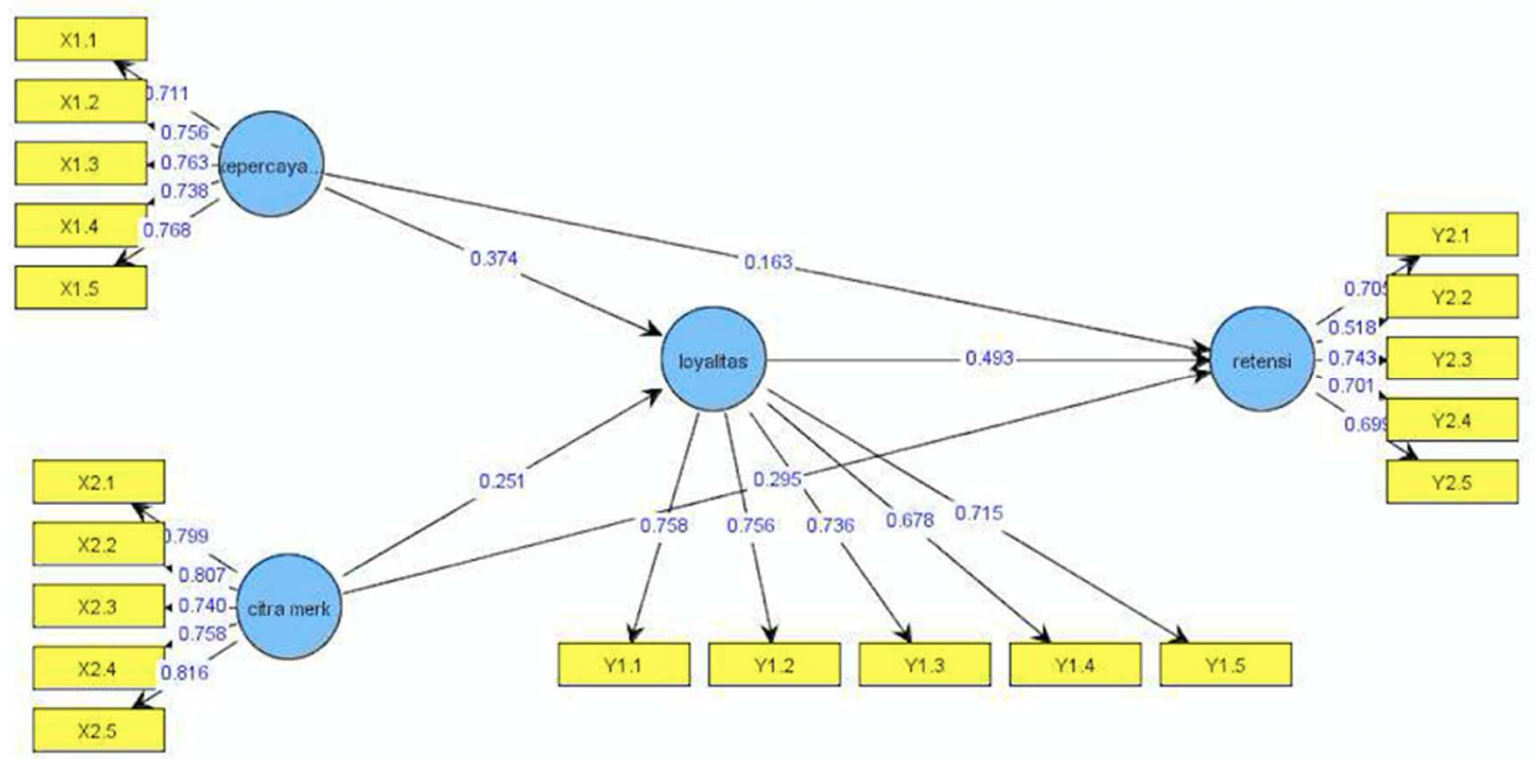

Figure 1.Path Analysis 
The results of the inner model can be seen in Table 3 .

Table 3.The Result of Inner Model

\begin{tabular}{|c|c|c|c|c|}
\hline & $\begin{array}{l}\text { Original Sample } \\
\text { Estimate }\end{array}$ & $\begin{array}{c}\text { Mean of } \\
\text { Subsample }\end{array}$ & $\begin{array}{l}\text { Standard } \\
\text { Deviation }\end{array}$ & $\begin{array}{c}\text { T- } \\
\text { Statistic }\end{array}$ \\
\hline Trust->Retention & 0,163 & 0,188 & 0,079 & 2,077 \\
\hline $\begin{array}{c}\text { Brand Image -> } \\
\text { Retention }\end{array}$ & 0,295 & 0,315 & 0,144 & 2,049 \\
\hline Trust -> Loyalitas & 0,374 & 0,410 & 0,127 & 2,945 \\
\hline $\begin{array}{c}\text { Brand Image - } \\
\text { >Loyalty }\end{array}$ & 0,251 & 0,248 & 0,120 & 2,088 \\
\hline Loyalty-> Retention & 0,493 & 0,472 & 0,108 & 4,555 \\
\hline
\end{tabular}

The path analysis model using the regression equation consists of two equations which are described as following in equation (3) and equation (4).

$$
\begin{aligned}
& \mathrm{Y} 1=\beta 1 \mathrm{X} 1+\beta 2 \mathrm{X} 2+\mathrm{e} 1 \\
& \mathrm{Y} 2=\beta 1 \mathrm{X} 1+\beta 2 \mathrm{X} 2+\beta 3 \mathrm{Y} 1+\mathrm{e} 2
\end{aligned}
$$

moreover, The regression equations can be described as following equation (3), Loyalty = 0.374 Trust +0.251 Brand Image + e1., for equation (4), Retention $=0.163$ Trust +0.295 Brand Image +0.493 Customer Loyalty + e2

Based on the PLS test calculation results, which test the effect of trust on customer retention, the t-statistical value test results are 2.077 and $t$-table 1.96. Meanwhile, the estimated coefficient (B) is 0.163 . Hence, it can be concluded that there is a positive and significant influence among the trust variable on the customer retention variable for Islamic commercial bank customers. This means that the higher the trust, the higher the customer retention. Therefore, the test results are accepted.

The results of the PLS test calculation test the effect of trust on customer loyalty. The results of the t-statistical value test are 2.945 and t-table 1.96, while the estimated coefficient $(ß)$ is 0.374 . So, it can be concluded that there is a positive and significant influence among the trust variable on the customer loyalty variable for Islamic commercial bank customers. This means that the higher the trust, the higher the customer loyalty. For this reason, the test results are accepted.

Based on the PLS test calculation results that test the effect of customer loyalty on customer retention, the $t$-statistical test results are 4.555 and $t$ table 1.96, while the estimated coefficient (B) is 0.493 . Thus, it can be concluded that there is a positive and significant influence among the customer loyalty variable on the customer retention variable for customers of Islamic Commercial Banks. This means that the higher the customer loyalty, the higher the customer retention. So, the test results are accepted.

Testing the first hypothesis reveals that trust directly affects customer retention and indirectly affects customer retention through customer loyalty. The amount of the coefficient of direct and indirect effect can be calculated as follows: 
Direct Effect Trust $->$ Customer Retention $=(0.163)$. 0.184 .

Indirect Effect Trust $\rightarrow>$ Customer Loyalty $\rightarrow>$ Customer Retention $(0.374) \times(0.493)=$

The coefficient of the indirect effect is greater than the direct effect. So that the first hypothesis in this study is accepted, this means that the customer loyalty variable can mediate between the variables of trust in customer retention.

Based on the PLS test calculation results, which test the effect of brand image on customer retention, the t-statistical test results are 2.049 and t-table 1.96, while the estimated coefficient (B) is 0.295 . Hence, it can be concluded that there is a positive and significant influence among the brand image variable on the customer retention variable for Islamic Commercial Bank customers. This means that the higher the brand image, the higher the customer retention. Accordingly, the test results are accepted.

The PLS test calculation results that test the effect of brand image on customer loyalty, the $t$ statistical test results are 2.088 and $t$ table 1.96. Meanwhile, the estimated coefficient $(B)$ is 0.251 . So, it can be concluded that there is a positive and significant influence among the brand image variable on the customer loyalty variable for Islamic Commercial Bank customers. This means that the higher the brand Image, the higher the customer loyalty. For this reason, the test results are accepted.

The PLS test calculation results test the effect of customer loyalty on customer retention. The t-statistical value test results are 4.555 and $t$-table 1.96. Meanwhile, the estimated coefficient ( $(3)$ is 0.493 . Thus, it can be concluded that there is a positive and significant influence among the customer loyalty variable on the customer retention variable for customers of Islamic Commercial Banks. This means that the higher the customer loyalty, the higher the customer retention. Therefore, the test results are accepted.

The results of testing the second hypothesis testing claim that brand image directly affects customer retention through customer loyalty. The amount of the coefficient of direct and indirect effect can be calculated as follows:

Direct Effect Brand Image $->$ Customer Retention $=(0.295)$

Indirect Effect Brand Image $->$ Customer Loyalty $->$ Customer Retention $=(0.251) X$ $(0.493)=0.123$.

The direct effect coefficient is greater than the indirect effect. For that reason, the second hypothesis in this study is rejected. This means that the customer loyalty variable is not able to mediate (as an intervening variable) the effect of brand image on customer retention.

\section{R-Square}

The R-Square value in this study can be seen in Table 4.

Table 4. R- Square

\begin{tabular}{cc}
\hline Variable & R-Square \\
\hline Loyalty & 0,279 \\
Retention & 0,589 \\
\hline
\end{tabular}

Source: Processed Data, 2020. 
The R-Square value of the customer loyalty construct is 0.279 , which means that trust and brand image can explain the variance of customer loyalty by $27.9 \%$. The remaining $72.1 \%$ is influenced by other factors that are not examined in this study. Furthermore, the R-Square value is also found in the customer retention construct of 0.589 , which means trust, brand image, and customer loyalty can explain the customer retention variance of $58.9 \%$, and the remaining $41.1 \%$ is influenced by other factors not examined in this study.

\section{DISCUSSION}

The results of hypothesis 1 testing reveal that trust has a positive and significant effect on customer retention. The results of this study are in line with studies conducted by Liu dan $\mathrm{Wu}$ (2007), Ratih (2015), Tung and Carlson (2015), which declare that trust has a positive and significant effect on customer retention in the banking industry. This study is contrary to the survey conducted by Luhung and Kusumargiani (2015), which stated that trust has no significant effect on repeat purchases in the Islamic banking industry.

Hypothesis 2 testing results discover that brand image has a positive and significant effect on customer retention. The results of this study are in line with studies conducted by Nguyen dan Leblanc (1998), which state that company image can influence customer retention decisions. Brand image has a role in good customer retention as antecedents and consequences. This study is supported by Trasorras et al. (2009), which agrees that brand image has a positive and significant effect on customer retention in the banking industry. Meanwhile, this research disaffirms the study conducted by Veloutsou (2015), which claims that brand image has no significant effect on customer retention.

The results of hypothesis 3 testing state that trust has a positive and significant effect on customer loyalty. The results of research Tabrani (2018), Hoq (2012), Adzoyi (2018) agree that trust has significant implications in building customer loyalty. Trust is recognized as an important indicator in developing customer loyalty. Muslim and non-Muslim customers have a high level of trust in Islamic Banks because Islamic Banks are following sharia principles. Therefore, the customers who have a high level of trust will be more loyal to Islamic Banks. Meanwhile, this research contradicts the study conducted by Hussein (2016), which states that trust has no significant effect on customer loyalty.

The results of hypothesis 4 assert that brand image has a positive and significant effect on customer loyalty. The results of this study are in line with research by Espinosa (2018), which reveals that brands represent a strong feeling of customer commitment. A strong brand will have a positive influence on profitability and market share. This study is in line with a survey conducted by Hsieh dan $\mathrm{Li}(2008)$ that claims that a favorable brand image can increase customer loyalty. The higher the brand image, the higher customer loyalty. The results of this study contradict the research conducted by Upamannyu dan Mathur (2012), which believes that brand image has no significant effect on customer loyalty.

The result of hypothesis 5 testing uncovers that customer loyalty positively and significantly affects customer retention. The results of this study are in line with research conducted by Darzi dan Bhat (2018) and Hofman-Kohlmeyer (2016), which bring out the fact that loyalty can improve customer retention strategies. Customer loyalty provides many benefits, such as increasing sales and a closer bond with customers. This research contradicts the research conducted by Almohaimmeed (2019), which finds that customer loyalty has no significant effect on customer retention. 


\section{CONCLUSION}

The test results indicate that the fourth hypothesis is accepted. The variables of trust and brand image can mediate customer retention through customer loyalty. The results of this study are in line with the research conducted by Ranaweera \& Prabhu (2003), which reveal that trust has a positive and significant effect on customer retention. Meanwhile, this research contradicts the study conducted by Datta, Fraser, and Lebcir (2018), which finds that trust has no significant effect on customer retention with customer loyalty as an intervening variable.

Brand image has a direct effect on customer retention. However, the customer loyalty variable cannot mediate the brand image and customer retention variables. The results of this study are in line with research conducted by Chou \& Chen (2016) that agrees that brand image has no significant effect on customer retention with customer loyalty as an intervening variable. Meanwhile, this research contradicts the study conducted by Hsieh and Li (2008), which claims that brand image positively affects customer retention with customer loyalty as an intervening variable. The limitation of this study is that not all variables can be used as intervening variables. We recommend that you add the customer satisfaction variable for further research.

\section{REFERENCES}

Abosag, I., \& Farah, M. F. (2014). The influence of religiously motivated consumer boycotts on brand image, loyalty, and product judgment. European Journal of Marketing, 48(1112), 2262-2283. https:// doi.org/10.1108/EJM-12-2013-0737

Adzoyi, P. N., Blomme, R. J., \& Honyenuga, B. Q. (2018). Customer retention among hotels in an emerging market: An employee-based perspective. Advances in Hospitality and Leisure, 14, 57-73. https:// doi.org/10.1108/S1745-354220180000014004

Akintunde, O. A. (2016). Customer Relationship Management ( CRM ) and Customer Retention in Nigeria Banking Industry : A Strategic Standpoint University of Lagos, Nigeria, 10(2), 81-90.

Almohaimmeed, B. (2019). Pillars of customer retention: An empirical study on the influence of customer satisfaction, customer loyalty, customer profitability on customer retention. Serbian Journal of Management, 14(2), 421-435. https:// doi.org/10.5937/sjm14-15517

Andreassen, T. W., \& Lindestad, B. (1998). Customer loyalty and complex services. The impact of corporate image on quality, customer satisfaction and loyalty for customers with varying degrees of service expertise. International Journal of Service Industry Management, 9(1), 7-23. https:/ / doi.org/10.1108/09564239810199923

Chang, C. C., \& Hung, J. S. (2018). The effects of service recovery and relational selling behavior on trust, satisfaction, and loyalty. International Journal of Bank Marketing, 36(7), 1437-1454. https:/ / doi.org/10.1108/IJBM-07-2017-0160

Chou, C., \& Chen, M. (2016). A qualitative study on perceived value and loyalty: A moderated-mediation framework 知覺價值與忠誠之質性研究 - 調節中介架構. Corporate Management Review, 36(2), 105-122.

Chu, P. Y., Lee, G. Y., \& Chao, Y. (2012). Service quality, customer satisfaction, customer 
trust, and loyalty in an e-banking context. Social Behavior and Personality, 40(8), 12711284. https:/ / doi.org/10.2224/sbp.2012.40.8.1271

Coussement, K. (2014). Improving customer retention management through cost-sensitive learning. European Journal of Marketing, 48(3/4), 477-495. https:// doi.org/10.1108/ ejm-03-2012-0180

Darzi, M. A., \& Bhat, S. A. (2018). Personnel capability and customer satisfaction as predictors of customer retention in the banking sector: A mediated-moderation study. International Journal of Bank Marketing, 36(4), 663-679. https:// doi.org/10.1108/IJBM-04-2017-0074

Datta, P., Fraser, P., \& Lebcir, M. (2018). An investigation into the relationship between customer relationship marketing and customer retention: superstore retailing context in Bangladesh. Journal of Business \& Retail Management Research, 13(02), 20-36. https:// doi.org/10.24052/jbrmr/v13is02/art-03

Espinosa, J. A., Ortinau, D. J., Krey, N., \& Monahan, L. (2018). I'll have the usual: how restaurant brand image, loyalty, and satisfaction keep customers coming back. Journal of Product and Brand Management, 27(6), 599-614. https:/ / doi.org/10.1108/JPBM-10-2017-1610

Faullant, R., Matzler, K., \& Füller, J. (2008). The impact of satisfaction and image on loyalty: The case of Alpine ski resorts. Managing Service Quality, 18(2), 163-178. https://doi.org/10.1108/09604520810859210

Hanaysha, J. R. (2018). Customer retention and the mediating role of perceived value in retail industry. World Journal of Entrepreneurship, Management and Sustainable Development, 14(1), 2-24. https:// doi.org/10.1108/wjemsd-06-2017-0035

Hofman-Kohlmeyer, M. (2016). Customer Loyalty Program As a Tool of Customer Retention: Literature Review. CBU International Conference Proceedings, 4, 199-203. https://doi.org/10.12955/cbup.v4.762

Hoq, M. Z., Amin, M., \& Sultana, N. S. (2012). The Effect of Trust, Customer Satisfaction and Image on Customers' Loyalty in Islamic Banking Sector. SSRN Electronic Journal. https://doi.org/10.2139/ssrn.1851427

Hsieh, A. T., \& Li, C. K. (2008). The moderating effect of brand image on public relations perception and customer loyalty. Marketing Intelligence and Planning, 26(1), 26-42. https:// doi.org/10.1108/02634500810847138

Hussein, A. S. T. T., Singh, S. K., Farouk, S., \& Sohal, A. S. (2016). Knowledge sharing enablers, processes and firm innovation capability. Journal of Workplace Learning, 28(8), 484-495. https:// doi.org/10.1108/JWL-05-2016-0041

Johansson, U., Koch, C., Varga, N., \& Zhao, F. (2018). Country of ownership change in the premium segment: consequences for brand image. Journal of Product and Brand Management, 27(7), 871-883. https://doi.org/10.1108/JPBM-10-2017-1651

Kashif, M., Shukran, S. S. W., Rehman, M. A., \& Sarifuddin, S. (2015). Customer satisfaction and loyalty in Malaysian Islamic banks: A PAKSERV investigation. International Journal of Bank Marketing, 33(1), 23-40. https:/ / doi.org/10.1108/IJBM-08-2013-0084 
Liu, T.-C., \& Wu, L.-W. (2007). Customer retention and cross-buying in the banking industry: An integration of service attributes, satisfaction and trust. Journal of Financial Services Marketing, 12(2), 132-145. https:/ / doi.org/10.1057/palgrave.fsm.4760067

Luhung, A.A dan Kusumargiani, I.S. "Analisis Pengaruh Dimensi Customer Relationship Marketing terhadap Customer Retention (Studi Kasus Pada PT Bank Muamalat Indonesia Cabang Semarang". Jurnal Sains dan Perbankan Syariah. Vol.5 No. 2 (2015) : 47.

Milan, G. S., Slongo, L. A., Eberle, L., De Toni, D., \& Bebber, S. (2018). Determinants of customer loyalty: a study with customers of a Brazilian bank. Benchmarking, 25(9), 3935-3950. https:/ / doi.org/10.1108/BIJ-08-2017-0231

Mohd Kassim, N., \& Souiden, N. (2007). Customer retention measurement in the UAE banking sector. Journal of Financial Services Marketing, 11(3), 217-228. https:// doi.org/10.1057/palgrave.fsm.4760040

Narteh, B., \& Braimah, M. (2019). Corporate reputation and retail bank selection: the moderating role of brand image. International Journal of Retail and Distribution Management, 48(2), 109-127. https://doi.org/10.1108/IJRDM-08-2017-0164

Nguyen, N., \& Leblanc, G. (1998). The mediating role of corporate image on customers' retention decisions: An investigation in financial services. International Journal of Bank Marketing, 16(2), 52-65. https:/ / doi.org/10.1108/02652329810206707

Nillie, P., Blomme, R. J., \& Quarshie, B. (2013). Advances in Hospitality and Leisure, iii. https:// doi.org/10.1108/s1745-3542(2013)0000009019

Omoregie, O. K., Addae, J. A., Coffie, S., Ampong, G. O. A., \& Ofori, K. S. (2019). Factors influencing consumer loyalty: evidence from the Ghanaian retail banking industry. International Journal of Bank Marketing, 37(3), 798-820. https:/ / doi.org/10.1108/IJBM04-2018-0099

Preikschas, M. W., Cabanelas, P., Rüdiger, K., \& Lampón, J. F. (2017). Value co-creation, dynamic capabilities and customer retention in industrial markets. Journal of Business and Industrial Marketing, 32(3), 409-420. https://doi.org/10.1108/JBIM-10-2014-0215

Ranaweera, C., \& Prabhu, J. (2003). The influence of satisfaction, trust and switching barriers on customer retention in a continuous purchasing setting. International Journal of Service Industry Management, 14(3-4), 374-395. https:/ / doi.org/10.1108/09564230310489231

Ratih, F. ; H. J. (2015). Analisis pengaruh kualitas pelayanan, kualitas produk, kepercayaan, dan nilai nasabah terhadap, 5, 1-20.

Reiersen, J. (2019). Drivers of trust and trustworthiness. International Journal of Social Economics, 46(1), 2-17. https:/ / doi.org/10.1108/IJSE-01-2018-0025

Statistik Perbankan Syariah 2015-2019, diakses disitus https:/ /ojk.go.id/id pada 25 Januari 2020.

Tabrani, M., Amin, M., \& Nizam, A. (2018). Trust, commitment, customer intimacy and customer loyalty in Islamic banking relationships. International Journal of Bank 
Marketing, 36(5), 823-848. https:/ / doi.org/10.1108/IJBM-03-2017-0054

Trasorras, R., Weinstein, A., \& Abratt, R. (2009). Value, satisfaction, loyalty and retention in professional services. Marketing Intelligence and Planning, 27(5), 615-632. https:/ / doi.org/10.1108/02634500910977854

Tung, B., \& Carlson, J. (2015). Examining determinants of cross buying behaviour in retail banking. International Journal of Quality and Reliability Management, 32(8), 863-880. https:// doi.org/10.1108/IJQRM-11-2012-0148

Upamannyu, N. K., \& Mathur, G. (2012). Effect of Brand Trust, Brand Affect and Brand Image on Customer Brand Loyalty and Consumer Brand Extension Attitude in FMCG Sector. PRiMa: Practices and Research in Marketing, 3(2), 116-189.

Veloutsou, C. (2015). Brand evaluation, satisfaction and trust as predictors of brand loyalty: the mediator-moderator effect of brand relationships. Journal of Consumer Marketing, 32(6), 405-421. https://doi.org/10.1108/JCM-02-2014-0878

Yu, P. L., Balaji, M. S., \& Khong, K. W. (2015). Building trust in internet banking: A trustworthiness perspective. Industrial Management and Data Systems, 115(2), 235-252. https:// doi.org/10.1108/IMDS-09-2014-0262

Yu, T. W., \& Tseng, L. M. (2016). The role of salespeople in developing life insurance customer loyalty. International Journal of Retail and Distribution Management, 44(1), 22 37. https://doi.org/10.1108/IJRDM-06-2014-0074 